Katarzyna Stelmasiak

Akademia Sztuki Wojennej w Warszawie

(iD)

ORCID ID: 0000-0002-9925-7388
OBLICZA WOJNY

TOM $2 \cdot$ ARMIA KONTRA NATURA

ŁóDŹ2020 • ISBN 978-83-8220-057-7 • s. 157-173

http://dx.doi.org/10.18778/8220-057-7.08

\title{
WARUNKI NATURALNE WIRGINII JAKO TERENU DZIAŁAŃ WOJENNYCH PODCZAS WALK O NIEPODLEGŁOŚĆ STANÓW ZJEDNOCZONYCH W LATACH 1780-1781
}

Streszczenie. W niniejszym artykule przedstawiono środowisko naturalne Wirginii oraz wykazano, jaki miało ono wpływ na działania wojenne podczas rewolucji. Jako baza źródłowa do opisania warunków naturalnych stanu posłużyły Uwagi o państwie Wirginia autorstwa Thomasa Jeffersona. Pod względem geograficznym Wirginia jest wyjątkowo uprzywilejowaną krainą. Malowniczo położona nad Zatoką Chesapeake, ma zróżnicowany krajobraz. Wzdłuż wybrzeża ciągną się równiny, a w głębi lądu powierzchnia jest wyżynno-górska. Występują tutaj liczne rzeki, a największe z nich - James i Potomak - uchodzą głębokimi estuariami do Zatoki Chesapeake.

Ze względu na ukształtowanie terenu i niewielkie zasiedlenie, wojna w Wirginii przybrała inny charakter niż w Nowej Anglii. Zwarta i zwrotna armia lorda Charlesa Cornwallisa stosowała szybkie manewry. Na czele idących do ataku Anglicy ustawiali strzelców, a artylerii przeznaczali samodzielną funkcję. Doceniono także siłę kawalerii zarówno w ataku, jak i w odwrocie. Z kolei po stronie amerykańskiej główny ciężar obrony spoczął na oddziałach milicji.

Pierwsze działania wojenne podjęto w Wirginii jesienią 1780 r., ale właściwa ofensywa rozpoczęła się wiosną 1781 r. Anglicy zajęli stolicę stanu Richmond, a lord Cornwallis podjął śmiałą próbę ujęcia ówczesnego gubernatora Thomasa Jeffersona i co ważniejszych członków zgromadzenia stanowego. Szczęśliwym zbiegiem okoliczności rząd i legislatura Wirginii zostali uprzedzeni o grożącym niebezpieczeństwie, a Jefferson ratował się ucieczką ze swojej posiadłości Monticello nieopodal Charlottesville w środkowej Wirginii na 5 minut przed przybyciem Anglików. Do decydującego starcia doszło pod Yorktown. Armie francuska i amerykańska dotarły lądem i morzem do Wirginii na początku września 1781 r. i stanęły naprzeciw lorda Cronwallisa w dwukrotnie większej od niego sile. Osaczony i atakowany lord Cornwallis skapitulował 19 października. Po kapitulacji działania wojenne ustały i Anglicy uznali się za pokonanych w wojnie o niepodległość Stanów Zjednoczonych.

Słowa kluczowe: wojna, rewolucja amerykańska, Wirginia, warunki naturalne 
Uwarunkowania środowiska naturalnego mają niewątpliwy wpływ na prowadzenie różnego typu działań wojennych. Rzeźba terenu, układ hydrologiczny i klimat nierzadko decydowały o losach wojen. Przykładem tego typu zależności jest przebieg wojny o niepodległość Stanów Zjednoczonych w Wirginii. W niniejszym artykule pragnę przedstawić środowisko przyrodnicze tej najstarszej angielskiej kolonii oraz wykazać, jaki miało wpływ na działania wojenne podczas rewolucji.

Uwagi o państwie Wirginia autorstwa Thomasa Jeffersona posłużyły mi jako baza źródłowa do opisania warunków naturalnych tego stanu. Praca ta jest oparta na wielkim bogactwie materiałowym oraz danych liczbowych i świadczy o doskonałej znajomości kraju przez autora. Jefferson określił w niej granice stanu Wirginia wraz z ich historycznym rozwojem, podał informacje o rzekach, górach, wybrzeżu morskim i portach. Poza konkretnymi danymi zamieścił znakomite opisy górskiego krajobrazu, rozległych dolin i potężnych rzek. W kolejnych rozdziałach scharakteryzował klimat i bogactwa naturalne stanu, przedstawił białych mieszkańców i tubylców oraz opisał siły zbrojne i marynarkę. Dlatego Uwagi stanowią pierwszorzędne źródło wiedzy o Wirginii ${ }^{1}$.

Pod względem geograficznym Wirginia jest wyjątkowo uprzywilejowaną krainą, a warunki przyrodnicze zadecydowały o jej rozwoju. Malowniczo położona nad Zatoką Chesapeake, ma zróżnicowany krajobraz. Wzdłuż wybrzeża ciągną się równiny stanowiące fragment Niziny Atlantyckiej. Z kolei w głębi lądu powierzchnia jest wyżynno-górska, a główne łańcuchy - Allegheny i Pasmo Błękitne należą do systemu Appalachów. W połowie XVIII w. Wirginia swoim zasięgiem obejmowała nie tylko tereny dzisiejszej Wirginii, ale także Wirginii Zachodniej, Kentucky, Ohio i Indiany oraz rościła sobie prawa do współczesnych terytoriów Illinois, Michigan i Wisconsin. Było to prawdziwe imperium, które rozciągło się od wybrzeży Atlantyku w kierunku zachodnim. Jefferson pisał w Uwagach, że granicą na wschodzie był ocean, a na północy równoleżnik przecinający wschodnie wybrzeże około $37^{\circ} 57^{\prime}$ N. Stamtąd w przybliżeniu północna granica przebiegała wzdłuż rzek Cinquac i Potomak, a dalej równolegle do przedłużenia linii Masona-Dixona ${ }^{2}$, dochodząc aż do rzeki Ohio.

\footnotetext{
1 T. Jefferson, Uwagi o pansstwie Wirginia, tłum., wstęp i oprac. T. Wieciech, Kraków 2014.

2 Linia Masona-Dixona została wyznaczona w latach 1763-1767 przez Charlesa Masona (1728-1786) i Jeremiaha Dixona (1733-1779) w celu rozwiązania sporu o przebieg granicy pomiędzy koloniami: Pensylwanią, Wirginią, Delaware i Maryland. Vide: T. Jefferson, op. cit., s. 5.
} 
Na zachodzie granicę wyznaczały rzeki Ohio i Missisipi do 36³0’ N. Na południu granica przebiegała równoleżnikowo od wspomnianego powyżej punktu nad rzeką Missisipi do brzegów Atlantyku. Z wyliczeń Jeffersona wynikało, że Atlantyk od Missisipi był oddalony o 758 mil (około $1220 \mathrm{~km}$ ) i były to poprawne kalkulacje. Wirginia kształtem przypominała trójkąt, miała powierzchnię $121525 \mathrm{mil}^{2}$ (około $314750 \mathrm{~km}^{2}$ ) i była prawie o $1 / 3$ większa od Wielkiej Brytanii i Irlandii ${ }^{3}$.

W Wirginii krainy geograficzne rozłożone są południkowo. Jefferson pisał w Uwagach, że góry „nie są pojedyncze i rozsiane w nieładzie po powierzchni kraju”, ale rozciągają się „około 150 mil [około $241 \mathrm{~km}$ ] od wybrzeża”, położone są równolegle do niego i składają się z kilku łańcuchów ułożonych w pasmach jedno za drugim. W rzeczywistości jest to kręgosłup kraju pomiędzy Atlantykiem z jednej strony a Missisipi i Rzeką św. Wawrzyńca z drugiej. Pomiędzy najwyższym i najbardziej malowniczym Pasmem Błękitnym a Alleghenami znajdują się liczne doliny. Zdaniem Jeffersona patrząc z oddali na Pasmo Błękitne odnosiło się wrażenie, że ,jest ono równie łagodne i urzekające, jak dzikie i potężne”. „Straszliwe zwały skał zwisają we fragmentach” kontrastując ze spokojem panującym w dolinach. „Ta sceneria warta jest wyprawy przez Atlantyk". W połowie XVIII w. nie oszacowano jeszcze wysokości Appalachów. Dyplomata dobrze przypuszczał, że Pasmo Błękitne jest najwyższe, ale pomylił się pisząc, że „najwyższy szczyt może mieć około $4000 \mathrm{ft}$ [około $1219 \mathrm{~m}$ ]”. Tymczasem najwyższe wzniesienie - góra Mitchell ma wysokość 6684 ft n.p.m. (2037 m n.p.m.) i przez większą część roku jest spowita we mgle i chmurach ${ }^{4}$.

W Wirginii występują liczne rzeki, a największe z nich - James i Potomak - uchodzą głębokimi estuariami do Zatoki Chesapeake. Jefferson pisał, że „James i Potomak wciskają się we wszystkie pasma górskie na wschód od Alleghenów” umożliwiając w ten sposób poznanie środkowej części kraju. Dyplomata uważał, że przeprawa Potomakiem przez Pasmo Błękitne „jest być może jednym z najbardziej zachwycających obrazów natury”. Istnienie naturalnych szlaków wodnych w znacznej mierze przyczyniło się do rozwoju białego osadnictwa

${ }^{3}$ W Uwagach Jefferson wymienił kilka powodów, które zadecydowały o kształcie terytorialnym stanu Wirginia około 1780 r. Były to m.in. nadania ziemskie z czasów kolonialnych, pokój paryski z 1763 r., układy graniczne zawierane z sąsiednimi stanami oraz przekazanie Kongresowi przez Wirginię ziem leżących po północnej stronie rzeki Ohio. Vide: T. JEFFERSON, op. cit., s. 6-7.

${ }^{4}$ Ibidem, s. 24-27. 
na tym terenie, ponieważ spławne rzeki ułatwiały transport towarów i płodów rolnych bezpośrednio w głąb lądu. Natomiast podczas wojny żeglowne rzeki ułatwiały penetrację terenu przez wojska nieprzyjaciela. W grudniu $1780 \mathrm{r}$. flota angielska z wojskami desantowymi dowodzonymi przez gen. Benedicta Arnolda wpłynęła do Zatoki Chesapeake i posuwając się po rzece James zagroziła stolicy stanu Wirginia - Richmond. Liczne rzeki mogły być także wyzwaniem dla wojsk angielskich. Zatoka Chesapeake położona jest na południu, więc szlaki wodne rzadko tutaj zamarzały na całym swoim biegu, natomiast często wylewały i tworzyły naturalne przeszkody. W wielu miejscach powstawały niebezpieczne wiry lub płycizny. Dlatego tak ważne było rozpoznanie terenu. Jefferson wspominał o tego typu utrudnieniach opisując m.in. rzekę Tanissee - choć jej „nurt jest umiarkowany” $i$,jest ona żeglowna dla załadowanych łodzi niezależnie od tonażu”, to kiedy przepływa przez wyżynę Cumberland „płycizny ciągną się przez 6 lub 8 mil [około 9,7 lub 12,9 km]" i „są możliwe do pokonania przez załadowanie łódki w dół rzeki, ale nie w górę, chyba że w razie jej wezbrania. [...] Także ta rzeka ma swoje wylewy”, a „powyżej miasta Chickamogga jest wir [...], który wciąga pnie drzew i łodzie, wyrzucając je ponownie pół mili [około $800 \mathrm{~m}$ ] poniżej. Można go uniknąć, trzymając się bardzo blisko brzegu po południowej stronie"s.

Ważnym elementem wpływającym na przebieg działań wojennych jest klimat. W Wirginii panuje klimat podzwrotnikowy morski, który sprzyjał osadnictwu, ponieważ zimy są łagodne i wilgotne, a lata gorące, słoneczne i raczej suche. Co prawda zdarzały się takie zimy jak na przełomie 1779 i 1780 r., kiedy Zatoka Chesapeake „była skuta lodem od jej czoła do ujścia Potomaku”, a „w Annapolis, gdzie pomiędzy najbliższymi punktami lądu ma ona szerokość $51 / 4$ mili [około $8,45 \mathrm{~km}$ ], lód był gruby na 5 do 7 cali [około $13-18 \mathrm{~cm}$ ] na całej szerokości, tak że przejeżdżały po nim załadowane powozy”, to na ogół zimy były tutaj niemroźne, a opady śniegu niewielkie. Śnieg, poza obszarami górskimi, padał rzadko i utrzymywał się przez jeden do trzech dni. Jefferson pisał, że przez 40 lat na wzgórzu Monticello, „które znajduje się w najbardziej na wschód wysuniętym paśmie górskim, nazywanym South West, [...] zdarzyły się ledwie dwa przypadki utraty owoców na wielką skalę" z powodu silnego mrozu, a sadzonki tytoniu były nadal zielone podczas Świąt Bożego Narodzenia. Dla lepszego zobrazowania klimatu Wirginii dyplomata wymienił rośliny mało

5 Ibidem, s. 15-16, 25. 
odporne na mrozy, które z powodzeniem były tam uprawiane: figi, granaty, karczochy i europejskie orzechy włoskie. Nawet „aloes rósł w Williamsburgu na otwartej przestrzeni przez ostrą zimę na przełomie 1779 i 1780 roku”. W Uwagach Jefferson zaznaczył jednak, że w tak „rozległym kraju będzie oczywiście można się spodziewać, że klimat nie jest taki sam we wszystkich jego częściach. [...] W miarę jak posuwamy się wzdłuż tego samego równoleżnika szerokości geograficznej w kierunku zachodnim, klimat staje się chłodniejszy w taki sam sposób, jak wówczas, gdy posuwamy się w kierunku północnym”. W Alleghanach, które są „najwyższym punktem lądu pomiędzy oceanem a Missisipi”, jest najchłodniej. Natomiast po przekroczeniu gór, ,jeśli możemy dać wiarę podróżnikom” jest cieplej „aniżeli na tej samej szerokości geograficznej nad brzegiem morza”. Podczas gdy stosunkowo łagodne zimy sprzyjały wojsku, to upalne lato stanowiło duże wyzwanie. Działania wojenne toczyły się na rozległych obszarach, poprzecinanych licznymi rzekami, pokrytych bagnami i lasami. Częściej zdarzały się tereny z nadmiarem wody, ale było i tak, że jej brakowało. Zmuszało to Anglików do stosowania innej taktyki walki niż w Europie. Dotychczasowe potyczki i forsowne marsze pokazały, że należało unikać atakowania kolumnami piechoty, szczególnie na otwartym terenie. Oficerowie angielscy musieli zdejmować ze swoich mundurów błyszczące i widoczne z daleka epolety, a eleganci obcinali długie włosy, które przeszkadzały w przedzieraniu się przez zarośla ${ }^{6}$.

Naturalną szatę roślinną Wirginii stanowiły bowiem gęste lasy, zwłaszcza liściaste. Do najczęściej spotykanych drzew należały brzozy, buki, dęby i klony. W Uwagach Jefferson wymienił około 140 gatunków rodzimych roślin. Wśród nich drzewa: platany, topole, klony i kasztanowce oraz różne gatunki sosen, świerków, dębów i brzóz. Walczący napotykali trudno dostępne tereny leśne, ale to żołnierze nieprzyjaciela mieli większe problemy z rozpoznaniem okolicy i przedarciem się przez nieznane sobie knieje. Dlatego Anglicy wzorem patriotów zaczęli tworzyć samodzielne oddziały strzelców, którzy, sami niewidoczni dla przeciwnika, ukryci w lesie, w krzakach, mogli go razić, zadając duże starty przy niewielkich własnych ${ }^{7}$.

Opisując środowisko naturalne Wirginii warto podkreślić, że początkowo tylko równiny na wybrzeżu atlantyckim były zagospodarowane przez

${ }^{6}$ Ibidem, s. 106, 110-112. Vide: I. Rusinowa, Saratoga-Yorktown 1777-1781.Z dziejów wojny amerykańsko-angielskiej, Warszawa 1984, s. 141.

7 Vide: T. JefFERSON, op. cit., s. 49-50; I. Rusinowa, op. cit., s. 141. 
kolonistów. Pierwsza osada - Jamestown - założona w 1607 r., położona była na północnym brzegu Zatoki Chesapeake. Zaledwie na początku XVIII w. zainteresowano się wyżynami, a góry stanowiły naturalną barierę dla białego osadnictwa aż do końca czasów kolonialnych. Pierwszą znaczącą penetracją terenów położonych za Pasmem Błękitnym była ekspedycja gubernatora Alexandra Spotswooda, który w 1716 r. poznał dolinę rzeki Shenandoah. Gubernator zachęcał kolonistów do osiedlania się na tych terenach z powodu możliwości rozwoju intratnego handlu futrami. Poza tym nowi osadnicy byliby w stanie obronić zachodnią granicę Wirginii przed najazdami Indian i Francuzów. Ojciec Thomasa Jeffersona był jednym z pionierów na mało zaludnionych obszarach pogranicza i w latach trzydziestych XVIII w. założył tam swoją farmę. Dopiero wraz ze wzrostem liczby mieszkańców następowało przesuwanie się białego osadnictwa bardziej na Zachód. Wtedy zaczęły powstawać nowe plantacje i osady w głębi kraju. O rozmieszczeniu ludności decydowały warunki do rozwoju rolnictwa oraz bliskość rzek. W chwili wybuchu wojny o niepodległość Stanów Zjednoczonych tereny pomiędzy wybrzeżem a Pasmem Błękitnym były najludniejszym obszarem Wirginii ${ }^{8}$.

Lata poprzedzające rewolucję były okresem wzmożonego rozwoju Wirginii. Biali osadnicy posiadali stosunkowo dobre warunki do życia, zwłaszcza na nizinach. Ziemia - główne źródło utrzymania - nadal była dostępna. Uprawa tytoniu i jego sprzedaż przynosiły zadowalające dochody. Stale rosła liczba ludności, a proporcja pomiędzy liczbą kobiet i mężczyzn, tak niekorzystna w XVII w., wyrównała się. Na początku XVIII stulecia Wirginia liczyła około 200000 mieszkańców. Jefferson pisał w Uwagach, że w początkowym okresie istnienia kolonii przyrost liczby mieszkańców „był zmienny i nieregularny” głównie z powodu wojen i małej grupy osadników. Natomiast po 1654 r. stał się on „dość stały” i do roku 1772 liczba „wolnych mężczyzn powyżej 16-tego roku życia oraz niewolników obu płci powyżej tego wieku [...] wzrosła z 7209 do $153000 "$ "

${ }^{8}$ Vide: Ch.R. Lindley, The Transition in Virginia from Colony to Commonwealth, New York 1967, s. 14-16; M.J. Rozbicki, Wirginia, Maryland i Karolina, [w:] Historia Stanów Zjednoczonych, red. M.J. Rozbicki, I. WAwrzyczeK, Warszawa 1995, t. 1, s. 60-61.

9 W Uwagach Thomas Jefferson przytoczył także dane pośrednie z lat: 1700, 1748 i 1759. Na ich podstawie doszedł do wniosku, że wzrost liczby mieszkańców Wirginii wykazywała charakter stały. Raz na każde 271/4 roku ludność kolonii podwajała się. Vide: T. JEFFERson, op. cit., s. 114-116. Z kolei szczegółowe dane o wyrównywaniu proporcji płci w Wirginii przytacza I. WAWrzyczeK, Planting 
Warto podkreślić, że przez cały okres kolonialny Wirginia pozostawała krajem rolniczym. Co prawda władze czyniły starania na rzecz rozwoju miast, ale pod koniec XVIII w. Jefferson pisał, że nie było tam żadnych znaczących ośrodków miejskich. Najludniejsze miasto Wirginii - Norfolk „liczył ledwie 6000 mieszkańców”, a Williamsburg - stolica kraju do 1780 r., „nigdy nie liczył powyżej 1800". Z kolei inne miejscowości były właściwie osadami lub większymi wioskami. Słabe zurbanizowanie Wirginii wynikało przede wszystkim z oparcia jej gospodarki na uprawie tytoniu. Jako że tytoń szybko wyjaławiał ziemię, uprawę trzeba było często przenosić. Dlatego domostwa budowano niestarannie, rozrzucone z rzadka wśród rozległych terenów leśnych i bagiennych, na niewielkich wykarczowanych polach. Jefferson pisał, że „prywatne budynki bardzo rzadko są stawiane z kamienia lub cegły, zdecydowana większość jest z belek i desek łączonych lepem”. Natomiast najbiedniejsi „budują chaty z kloców kładzionych poziomo warstwami, zatykając szpary błotem”. Były one „cieplejsze zimą i chłodniejsze latem” i pod tym względem lepsze „aniżeli kosztowne konstrukcje z belek i desek". Same plantacje były dużych rozmiarów, tak że poszczególne majątki pozostawały w znacznej mierze samowystarczalne. Ludzie żyli w pewnym oddaleniu od siebie i utrzymywali nikłe kontakty sąsiedzkie. Nie powstawały także ośrodki portowe, ponieważ istniały liczne szlaki wodne umożliwiające bezpośredni wywóz tytoniu na statki, które dostarczały go do Anglii. Pośrednictwo miast było po prostu zbyteczne. Jefferson podsumowywał: „nasz kraj jest wielce poprzecinany żeglownymi wodami, a handel docierał prosto pod nasze drzwi, nie zmuszając nas do wypraw w jego poszukiwaniu"10.

W związku z niewielkim zasiedleniem terenu wojna w Wirginii i na całym Południu różniła się znacznie od znanych dowódcom angielskim wojen europejskich. Działania wojenne przybrały inny charakter. Na czele idących do ataku Anglicy ustawiali strzelców, a artylerii przeznaczali samodzielną funkcję w natarciu. Ruchy wojsk nieprzyjaciela wymuszały stosowanie szybkich manewrów i niejednokrotnie natychmiastowego działania. Ze względu na ukształtowanie terenu Anglicy docenili także siłę kawalerii zarówno w ataku, jak i w odwrocie.

and Loving. Popular Sexual Mores in the Seventeenth-Century Chesapeake, Lublin 1998, s. 20. Liczbę mieszkańców Wirginii na początku XVIII w. podaje Z. MAZUR, The Power of Play: Leisure, Recreation and Cultural Hegemony in Colonial Virginia, Lublin 2010, s. 17.

${ }^{10}$ Vide: T. JefFerson, op. cit., s. 146-147; 205. Szerzej o sposobie uprawy tytoniu pisze: Z. LEWICKI, Historia cywilizacji amerykańskiej. Era tworzenia 1607-1789, Warszawa 2009, s. 48-52. 
Zwarta, szybka armia lorda Charlesa Cornwallisa działająca na Południu w 1780 r. znacznie różniła się od powolnej, obarczonej licznymi taborami armii angielskiej z początku wojny o niepodległość Stanów Zjednoczonych. Z kolei po stronie amerykańskiej główny ciężar obrony Południa spoczął na oddziałach milicji. W Wirginii „każdy sprawny, wolny mężczyzna w wieku od 16 do 50 lat” był wciągany „do rejestru milicji”. Jefferson pisał w Uwagach, że w hrabstwach formowano kompanie, które z kolei tworzyły „jeden lub więcej batalionów, stosownie do populacji hrabstwa”. „W każdym hrabstwie był porucznik hrabstwa, który dowodził całą milicją swojego hrabstwa”. Wirginia nie posiadała zawodowych oficerów w stopniu generała. Byli oni mianowani okazjonalnie w razie potrzeby, a ich dowództwo wygasało wraz z ustaniem zagrożenia. Na czele władzy wojskowej i cywilnej stał gubernator stanu. Zgodnie z prawem każdy członek milicji musiał wyposażyć się sam „w broń typową w regularnej służbie”. Jednak jak zauważał Jefferson „nakaz ten był zawsze marnie realizowany, a broni, którą miała milicja, tak często domagano się dla uzbrojenia regularnych oddziałów, że w dolnych obszarach kraju jest ona całkowicie rozbrojona”. W środkowej Wirginii co czwarty lub piąty członek milicji posiadał rusznicę, taką, „w jakie zaopatrzono się w celu zwalczania nieznośnych zwierząt będących utrapieniem farm", a po zachodniej stronie Pasma Błękitnego członkowie milicji byli na ogół uzbrojeni w strzelby. Każdy z nich posiadał konia, ponieważ przy dużych odległościach wydatnie ułatwiał przenoszenie się z miejsca na miejsce. Bez koni oddziały milicji nie mogłyby funkcjonować, zdobywać pożywienia i informacji. Część oddziałów milicji prowadziła walkę partyzancką. Urządzali oni szybkie rajdy na położone w głębi stanu posterunki angielskie i przerywali im linie dostawcze. Przed partyzantką działającą w różnych częściach Wirginii Anglicy praktycznie nie byli w stanie się bronić. Partyzanci trzymali ten obszar w nieustającym zagrożeniu i przyczynili się do rozproszenia sił wroga. Ich przewaga nad regularną armią wynikała m.in. z faktu, że w tych oddziałach duży odsetek stanowili mieszkańcy terenów podgórskich, którzy od najmłodszych lat byli przyzwyczajeni do życia w siodle i ze strzelbą w dłoni. Niestety walki typu partyzanckiego były dla obu stron bardzo wyczerpujące. Patrioci nie mieli zorganizowanej służby medycznej i każde, nawet niegroźne zranienie w gorącym i dusznym klimacie, bez zachowania odpowiedniej higieny, prowadziło do śmierci. Poza tym partyzantom zaczynało brakować żywności i koni. Stąd wynikała płynna liczebność oddziałów milicji. Jefferson pisał, że położenie 
oddziałów milicji, tak jak i oddziałów regularnych ,jest nieustannie zmienne”, a ich „stan tego dnia nie odpowiadałby jego stanowi za miesiąc. Ich położenie jest w dużej mierze takie samo jak położenie innych oddziałów kontynentalnych"11.

Warto podkreślić, że do $1780 \mathrm{r}$. Wirginia pozostawała poza głównym nurtem działań wojennych. Nie oznaczało to jednak, że nie ponosiła ciężaru wojny. Mieszkańcy stanu wnieśli znaczący wkład militarny formując trzy pułki, które walczyły na froncie północnym. Poza tym Wirginia zaopatrywała Armię Kontynentalną w zapasy żywności, ubrania i dodatkowy sprzęt. Część pieniędzy zebranych z podatków była przeznaczana na cele wojenne. Niestety wojna o niepodległość przewlekała się i Wirgińczycy, tak jak mieszkańcy innych stanów, coraz gorzej znosili trudy i wyrzeczenia. Członkowie zgromadzenia stanowego ubolewali nad faktem, że musieli wysyłać wsparcie militarne poza granice w obliczu potencjalnego zagrożenia wewnątrz stanu. Zarazem Wirginia zaczęła zmagać się z kryzysem gospodarczym. Jej bogactwo stanowił tytoń, którego uprawa dzięki pracy niewolników była nadal efektywna i w dalszym ciągu opłacalna. Tytoń trzeba było jednak eksportować, a to w czasie wojny stawało się coraz trudniejsze z powodu blokady portów. Część kupców opowiadała się nawet za szybkim zakończeniem wojny z powodu niekorzystnej sytuacji na rynku. Tylko sprzedaż tytoniu do Europy gwarantowała napływ pieniądza kruszcowego do Ameryki, ale z powodu ograniczenia handlu, na rynku zaczęło go brakować. Stąd w obrocie wewnętrznym pojawiły się pieniądze papierowe emitowane przez rządy stanowe co w krótkim czasie doprowadziło do inflacji i drożyzny. Skarb był pusty i pojawiła się spekulacja. Do tego słabe były plony i pod koniec 1779 r. Wirginia po raz pierwszy musiała importować żywność z sąsiedniego Marylandu ${ }^{12}$.

Tymczasem konflikt przesunął się w kierunku południowym. Przystąpienie Francji do wojny w 1778 r. i jej zainteresowanie Indiami Zachodnimi sprawiły, że marynarka angielska zaczęła aktywnie operować w rejonie wysp cukrowych, które miały dla Anglii ogromne znaczenie. To spowodowało przeniesienie działań lądowych na Południe, bliżej zagrożonych wysp. Plan angielski zakładał zdobycie położonej najbardziej na południe Georgii, a następnie stopniowe przesuwanie się na północ przy wydatnej pomocy lojalistów zamieszkujących tereny wiejskie. Strategia ta okazała się bardzo skuteczna i od końca 1778 do 1780 r.

\footnotetext{
11 Vide: T. JefFerson, op. cit.s. 125; I. Rusinowa, op. cit., s. 141-142.

12 Vide: Z. Libiszowska, Tomasz Jefferson, Wrocław 1984, s. 75.
} 
wojska Konfederacji poniosły szereg porażek. W listopadzie 1778 r. gen. Henry Clinton - głównodowodzący wojsk angielskich, wysłał z Nowego Jorku i New Jersey 3500 żołnierzy w okolice miasta Savannah. Przybyli Anglicy byli znacznie silniejsi od Amerykanów. Wspierani przez lojalistów bez trudu zajęli miasto w końcu grudnia 1778 r., a w kilka dni później stolicę stanu, Augustę. W ciągu niespełna miesiąca stłumiono opór wewnątrz kraju i niemal cała Georgia ponownie stała się kolonią angielską.

Na wieść o zajęciu Georgii Kongres postanowił zmobilizować siły i nie dopuścić do utraty obu Karolin i Wirginii, tym bardziej że zagrożone tereny należały do najbogatszych w nowo powstałych Stanach Zjednoczonych. Uprawiano tam cenne rośliny mające duże znaczenie handlowe (tytoń, ryż, indygowiec), a tamtejsze lasy sosnowe dostarczały żywicy, smoły i terpentyny, w które zaopatrywano statki. Dowódcą amerykańskiej armii na Południu został gen. Benjamin Lincoln, który z niewielkim oddziałem żołnierzy przybył do Charlestonu w Karolinie Południowej. Podczas marszu do 1000 żołnierzy Armii Kontynentalnej dołączyły oddziały milicji z Karoliny Północnej i Wirginii. W sumie gen. Lincoln dowodził około 6000 żołnierzy. Jednocześnie flota francuska działająca w Indiach Zachodnich miała wesprzeć Amerykanów. Plan zakładał wspólne amerykańsko-francuskie oblężenie i atak na Savannah, a następnie odbicie Georgii. Oblężenie miasta rozpoczęto 23 września 1779 r. W skład wojska amerykańskiego wchodził m.in. legion dowodzony przez gen. Kazimierza Pułaskiego. Niestety generalny atak przeprowadzony 9 października przyniósł Amerykanom klęskę, a dla Pułaskiego zakończył się tragicznie. Rannego Polaka przeniesiono na stojący w porcie nieduży okręt. Odniesiona rana nie była śmiertelna, ale wywołała infekcję. Brak właściwej opieki lekarskiej spowodował, że w dwa dni później, 11 października 1779 r., Pułaski zmarf ${ }^{13}$.

Przegrana pod Savannah przyczyniła się do opuszczenia przez flotę francuską amerykańskich wybrzeży, gen. Lincoln odmaszerował ze swoimi żołnierzami do Charlestonu, a Georgia pozostała pod kontrolą angielską do 1782 r. stanowiąc doskonałe zaplecze do dalszych działań. Na początku 1780 r. Anglicy

13 Vide: I. Rusinowa, op. cit., s. 128-133; eadem, Geneza Stanów Zjednoczonych Ameryki Pótnocnej. (Unia z lat 1774-1783), Warszawa 1974, s. 273-277. Szerzej o służbie Kazimierza Pułaskiego w szeregach Armii Kontynentalnej czytaj m.in. w: L. Pastusiak, Polacy u narodzin Stanów Zjednoczonych, Warszawa 2016, s. 88-122; IDEm, Polacy w wojnie o niepodlegtość Stanów Zjednoczonych. Kościuszko, Putaski i inni, Warszawa 2015, s. 89-120. 
bez problemu przeprowadzili atak na Karolinę Południową. W lutym gen. Clinton rozpoczął oblężenie Charlestonu. Pomimo że miasto było dobrze ufortyfikowane, to siły obrońców okazały się niewystarczające. Po trzech miesiącach, 12 maja, Amerykanie skapitulowali. Była to jedna z najgorszych amerykańskich porażek w wojnie o niepodległość. Do niewoli dostało się wówczas 5500 żołnierzy, w tym dziesięć regimentów z Wirginii. Do połowy maja cała Karolina Południowa znalazła się pod kontrolą angielską. Wtedy Kongres zwrócił się do zdobywcy Saratogi, gen. Horatio Gatesa, powierzając mu dowództwo i polecając marsz na Południe. Niestety w połowie sierpnia jego oddziały zostały zatrzymane przez siły lorda Cornwallisa i rozbite w bitwie pod Camden (16 sierpnia 1780 ${ }^{14}$.

Po zajęciu Charlestonu siły angielskie rozdzieliły się. Generał Clinton wraz z 1/3 oddziałów biorących udział w oblężeniu miasta popłynął do Nowego Jorku, a do dalszego opanowania prowincji południowych został wyznaczony lord Cornwallis. Rozdzielenie wojska było spowodowane przybyciem do Ameryki w lecie 1780 r. francuskiego korpusu gen. Jean-Baptiste de Rochambeau, który wylądował w Newport w stanie Rhode Island. Anglicy przez rok blokowali Francuzów, co wiązało ich siły na północy. W tym czasie lord Cornwallis z trudem sprawował kontrolę nad Karoliną Południową i kiedy wyruszył do Karoliny Północnej, za jego plecami wybuchła rebelia wspierana przez oddziały gen. Nathanaela Greene’a - nowego dowódcy amerykańskiej armii na Południu. Greene - zdając sobie sprawę, że brakowało mu żołnierzy - stosował taktykę zaskakujących przeciwnika akcji, które okazały się nadzwyczaj skuteczne. Pomimo że lord Cornwallis zadał Greene’owi kilka dotkliwych ciosów i tak nie był w stanie pokonać go definitywnie. Dlatego pozostawiwszy losowi nieujarzmione obie Karoliny podjął wiosną 1781 r. próbę podboju Wirginii i zbliżenia się do północnej armii gen. Clintona ${ }^{15}$.

Pierwsze działania ofensywne w Wirginii podjęto jeszcze w październiku 1780 r. Na prośbę lorda Cornwallisa gen. Clinton wysłał tam gen. mjr Alexandra Lesliego z 2200 ludźmi w celu przeprowadzenia dywersji na rzecz Anglików. Sądzono, że obecność nieprzyjaciela uniemożliwi Wirginii skierowanie posiłków do obu Karolin i być może doprowadzi do wycofania stamtąd części jednostek.

${ }^{14}$ Vide: G.B. Tindall, D.E. Shi, Historia Stanów Zjednoczonych, Poznań 2002, s. 227. Szerzej o bitwach pod Charleston i Camden vide: I. Rusinowa, op. cit., s. 134-151.

15 Vide: M.A. Jones, Historia USA. Narody i Cywilizacje, red. P. Skurowski, Gdańsk 2002, s. 67; E. Rostworowski, Historia Powszechna. Wiek XVIII, Warszawa 1994, s. 533. 
Zadaniem gen. Lesliego było zastraszenie ludności cywilnej i przecięcie rebelianckich linii zaopatrzenia. Anglicy zeszli na ląd w Portsmouth, Newport News i Hampton. Kawaleria i lekka piechota splądrowały półwysep pomiędzy rzekami James i York, a następnie dotarły pod Yorktown. Potem przeczesały wschodni kraniec Wirginii. Powołana pod broń milicja okazała się całkowicie bezsilna wobec Anglików i uległa rozproszeniu. Na szczęście dla Wirginii najazd został dość niespodziewanie przerwany po około 20 dniach, kiedy gen. Leslie otrzymał rozkaz dołączenia do armii lorda Cornwalisa ${ }^{16}$.

Pomimo że Anglicy wycofali się, Wirginia nie była bezpieczna. Kraj posiadał rozległe granice, morskie wybrzeża nie miały praktycznie żadnej ochrony, porty były otwarte i nieufortyfikowane, a kilka małych jednostek flotylli morskiej dysponowało łącznie kilkunastoma armatami. Jefferson pisał w Uwagach, że okręty „były przeważnie tak źle obsadzone, że rzadko nadawały się do służby”. Z tego powodu Wirginia pozostawała w zasadzie bezbronna, zdana jedynie na niedoświadczoną milicję, bez zaopatrzenia i broni. Tymczasem 30 grudnia $1780 \mathrm{r}$. angielskie okręty zostały dostrzeżone w Zatoce Chesapeake. Tego samego dnia flota dowodzona przez gen. Benedicta Arnolda dotarła do Jamestown, położonego 50 mil (około 80 km) w górę rzeki James. Generał Arnold wysadził połowę z 1600 swoich ludzi na brzeg. Anglicy splądrowali okoliczne farmy i przejęli mienie, w tym niewolników. Trzy dni później większość sił inwazyjnych nie napotykając oporu wkroczyła do nowej stolicy stanu - Richmond. W mieście znajdował się tylko niewielki oddział milicji, ponieważ członkowie zgromadzenia stanowego i większość mieszkańców nie czekając na wroga wyjechali na prowincję. Najeźdźcy bez trudu ograbili i spalili część stolicy. Łupem padły magazyny wojskowe, żywność i zapasy prochu oraz czekający na eksport najcenniejszy produkt wirgiński - tytoń. Jefferson donosił, że Anglicy „wjechali do Richmond o 1 po południu 5 stycznia. Spalili [...] młyn, magazyn i dwa inne budynki i udali się do Westham. Następnego ranka spalili kolejne budynki publiczne i prywatne"17.

Warto podkreślić, że jesienią 1780 r. Thomas Jefferson - ówczesny gubernator Wirginii - wiedział o ruchach wojsk nieprzyjaciela, ponieważ gen. George

${ }^{16}$ Vide: J. Ferling, Cud nad Potomakiem. Amerykańskie zwyciestwo w wojnie o niepodlegtość, Oświęcim 2019, s. 609.

${ }^{17}$ Vide: T. Jefferson, op. cit., s. 126; J. Ferling, op. cit., s. 610-611; Thomas Jefferson do George'a Waszyngtona, 10 I 1781, The Papers of Thomas Jefferson, wyd. J.P. BoyD, Princeton 1951, t. 4 , s. 334 . 
Waszyngton informował go na bieżąco o oddziałach stacjonujących w Nowym Jorku gotowych do wyprawy na Południe. Nie znał jej celu, ale ostrzegał, że gen. Arnold może ruszyć na Wirginię i dotrzeć do niej pod koniec roku. Jefferson, czekając na potencjalne uderzenie, stał przed trudną decyzją. W październiku, kiedy zaatakował gen. Leslie, zwołał milicję stanową, ale zanim większość milicjantów dotarła na front, Anglicy opuścili stan. Ponowna mobilizacja milicji w tak krótkim czasie mogłaby wywołać niezadowolenie, jeśli alarm okazałby się fałszywy, a gen. Arnold uderzyłby na Karoliny. Jefferson uważał, że tak właśnie się stanie. Dlatego postanowił czekać. Kiedy w końcu zdecydował się wezwać milicję, było już za późno. Anglicy niczym niepowstrzymywanym marszem, lądem i wodą, posuwali się w głąb kraju, dokonując po drodze dzieła zniszczenia. Jefferson nakazał jeszcze ewakuację magazynów państwowych. Po tym jak zatroszczył się o swoją rodzinę, powrócił do Richmond, ale dojeżdżając zobaczył miasto w płomieniach. Utrata stolicy obciążyła w opinii publicznej gubernatora ${ }^{18}$.

Anglicy szybko wycofali się z Richmond, ponieważ gen. Arnold otrzymał poufne informacje, że znajdujące się w Wirginii oddziały milicji i Armii Kontynentalnej zaczęły gromadzić się, aby odbić stolicę. Jako że oddział gen. Arnolda był niewielki i łatwo mógł być zniszczony, Anglicy pomaszerowali z powrotem do Portsmouth, gdzie zamierzali spędzić zimę i poczekać na postępy armii lorda Cornwallisa. W drodze powrotnej dokonali jednak dalszego zniszczenia, unosząc ze sobą wszystko, co tylko się dało i rujnując okolicę. Warto podkreślić, że obie angielskie akcje desantowe z października i grudnia 1780 r. miały w dużej mierze zadania dywersyjne i psychologiczne. Anglicy liczyli na złamanie woli walki Wirgińczyków i wycofanie się stanu z wojny. Cele to nie zostały jednak osiągnięte. Co więcej, rozgoryczony gubernator Wirginii snuł plany zorganizowania kontrakcji celem ujęcia gen. Arnolda. Planom tym udzielił poparcia gen. Waszyngton, który skierował gen. La Fayette’a z 1200 ludźmi do wykonania planu. Przewidywał on współdziałanie z lokalną milicją i flotą francuską. Wyprawa jednak nie w pełni się powiodła. Nie doszło do koordynacji sił morskich i lądowych. Generał Arnold zdołał się wymknąć na angielskim okręcie. Natomiast skupiona wokół Richmond dywizja La Fayette’a, wzmocniona z kwatery głównej, stanowiła teraz główną siłę zbrojną Wirginiii ${ }^{19}$.

\footnotetext{
18 Vide J. Ferling, op. cit., s. 610; Z. Libiszowska, op.cit., s. 84.

19 Vide: J. Ferling, op. cit., s. 610; Z. LibiszowsKa, op. cit., s. 85-86.
} 
Tymczasem wojna na Południu wchodziła w decydującą fazę, a Wirginia ponownie stała się terenem działań wojennych. 17 stycznia 1781 r. nowo sformowana armia amerykańska pod wodzą gen. Daniela Morgana pokonała oddział Anglików pod Cowpens w Karolinie Południowej. Zwycięstwo to stało się punktem zwrotnym, ważnym psychologicznie dla losów całej wojny o niepodległość. Dodało odwagi mieszkańcom Południa a przyczyniło się do upadku morale wśród Anglików i lojalistów. Wojska lorda Cornwallisa zaprzestały pacyfikacji Karoliny Południowej i przesunęły się bardziej na północ, aby dogonić wojska gen. Greene’a w Karolinie Północnej. Stało się to w Guilford Court House, gdzie 15 marca 1781 r. lord Cornwallis wygrał wprawdzie bitwę, ale straty, jakie poniósł, zmusiły go do wycofania wojsk w stronę wybrzeża. Natomiast gen. Greene wrócił do Karoliny Południowej, połączył tam swoje siły z oddziałami milicji i po serii brawurowych akcji partyzanckich, w wyniku których przegrywał poszczególne bitwy, wygrywał wojnę. W ten sposób do września 1781 r. ograniczył zasięg wojsk angielskich na dalekim Południu do miast Charleston i Savannah ${ }^{20}$.

Wojska lorda Cornwallisa były wyraźnie zmęczone całorocznymi działaniami na Południu. Pomimo to ich dowódca zadecydował o krótkim postoju w Wilmington w Karolinie Północnej, ponieważ zamierzał podjąć nową kampanię zanim nastanie upalne lato. Tym razem celem ataku stała się Wirginia. Lord Cornwallis uważał, że przed ostatecznym podbojem obu Karolin należało wyeliminować z wojny ten stan jako źródło zaopatrzenia dla Amerykanów. Zaledwie po 18 dniach odpoczynku 25 kwietnia 1781 r. wojska angielskie wyruszyły na brzemienną w skutki wyprawę. W drugim tygodniu maja armia lorda Cornwallisa wkroczyła na teren Wirginii. Stolica stanu - Richmond znowu była w niebezpieczeństwie. Jefferson pisał do gen. Waszyngtona, że Wirginia nie przetrwa bez pomocy innych stanów. „Gdyby w zaistniałych okolicznościach Wasza Ekscelencja udzieliła nam osobistej pomocy, [...] Wasze pojawienie się [tutaj] przywróciłoby wiarę w nasze ocalenie". W tej groźnej sytuacji zgromadzenie i rada stanu postanowity przenieść swoją siedzibę do Charlottesville - miasta położonego bardziej na północny zachód. Pierwsi opuścili stolicę posłowie i członkowie rady. Gubernator Jefferson zdecydował się na wyjazd 15 maja. Richmond pozostało puste i bezbronne. Wówczas lord Cornwallis postanowił podjąć śmiałą próbę ujęcia gubernatora i co ważniejszych członków zgromadzenia.

${ }^{20}$ Vide: G.B. Tindall, D.E. ShI, op. cit., s. 228. 
W tym celu płk Banastre Tarleton, z 250 budzącymi postrach dragonami, miał przeprowadzić rajd na Charlottesville i wziąć do niewoli całe kierownictwo polityczne i dowództwo wojskowe Wirginii. Szczęśliwym zbiegiem okoliczności rząd i legislaturę zdołał uprzedzić o grożącym niebezpieczeństwie płk John Jonett. Jefferson ratował się ucieczką ze swojej posiadłości Monticello nieopodal Charlottesville na 5 minut przed przybyciem Anglików. Pułkownik Tarleton zajął posiadłość gubernatora, ale nie zniszczył jej, chociaż jego ludzie zabrali te rzeczy, których właściciel nie zdążył ukryć21.

Po trzech tygodniach, głównie bezowocnych, marszów przez pokryte gęstą roślinnością obszary Wirginii lord Cornwallis postanowił pójść w dół rzeki James, do Williamsburga. Wycofując się poinformował gen. Clintona, że do opanowania całej prowincji potrzebna będzie znacznie większa armia, co głównodowodzący wojsk angielskich zlekceważył. Pod koniec czerwca Anglicy dotarli na półwysep pomiędzy estuariami rzeki York i James. Upał i duża wilgotność dokuczały żołnierzom, ale armia dysponowała tam obfitymi zapasami żywności. W tym czasie francuska flota admirała de Grasse’a, która dotąd działała głównie na Morzu Karaibskim, przypłynęła z 4000 żołnierzy na wody Zatoki Chesapeake, uniemożliwiając Anglikom ucieczkę morzem. Dzięki szybkiej i na czas wykonanej operacji, armie francuska i amerykańska dotarły lądem i morzem do Wirginii, gdzie na początku września stanęły naprzeciw lorda Cornwallisa w dwukrotnie większej od niego sile. Podjęta przez gen. Clintona próba morskiej odsieczy okazała się spóźniona. Osaczony i atakowany przeważającymi siłami lord Cornwallis 19 października 1781 r. skapitulował pod Yorktown. Po kapitulacji działania wojenne ustały i Anglicy uznali się za pokonanych w wojnie o niepodległość Stanów Zjednoczonych ${ }^{22}$.

Warto podkreślić, że w okresie sześciomiesięcznej okupacji Wirginii, od kwietnia do października 1781 r. wojska angielskie systematycznie pustoszyły cały stan, rabując mienie publiczne i prywatne przysparzając wielomilionowych strat. Wirginia była zniszczona, ale to na jej terytorium doszło do ostatecznego zwycięstwa, które powetowało wielokrotnie liczne porażki i upokorzenia. Natomiast Jefferson surowo krytykowany przez politycznych oponentów za niewłaściwe sprawowanie urzędu gubernatora postanowił porzucić służbę publiczną

21 Vide: J. Ferling, op. cit., s. 652-653; Z. LibiszowskA, op. cit., s. 86-87; Thomas Jefferson do George'a Washingtona, $28 \mathrm{~V}$ 1781, The Papers of Thomas Jefferson, t. 6, s. 32-33.

22 Vide: M.A. Jones, op. cit., s. 68; E. RostworowsKi, op. cit., s. 533-534. 
jesienią 1781 r. Swoje rozgoryczenie wyraził w liście do Jamesa Monroe: „Czuję, że te wszystkie rany, które mi zadano na mojej duszy, zostaną uleczone dopiero przez kojący grób”. Wrogowie zarzucali mu opuszczenie siedziby rządu w momencie krytycznym i udanie się do swojej posiadłości w Monticello. Miano mu za złe, że jako gubernator nie wykazał się należytą energią i samodzielnością. Nagonka przeciwko Jeffersonowi nie znalazła jednak w społeczeństwie dużego odzewu. Generał Waszyngton nigdy nie zgłosił pretensji pod jego adresem, wręcz przeciwnie, dziękował za jego ofiarną i ciężką służbę dla kraju ${ }^{23}$.

\section{BIBLIOGRAFIA}

\section{Źródła drukowane}

Jefferson T., Uwagi o państwie Wirginia, tłum., wstęp i oprac. T. Wieciech, Kraków 2014. The Papers of Thomas Jefferson, wyd. J.P. Boyd, Princeton 1951-1952, t. 4, 6.

\section{Opracowania}

Ferling J., Cud nad Potomakiem. Amerykańskie zwycięstwo w wojnie o niepodlegtośc,, Oświęcim 2019.

Jones M.A., Historia USA. Narody i Cywilizacje, red. P. Skurowski, Gdańsk 2002.

Lewicki Z., Historia cywilizacji amerykańskiej. Era tworzenia 1607-1789, Warszawa 2009.

Libiszowska Z., Tomasz Jefferson, Wrocław 1984.

Lindley Ch.R., The Transition in Virginia from Colony to Commonwealth, New York 1967.

Mazur Z., The Power of Play: Leisure, Recreation and Cultural Hegemony in Colonial Virginia, Lublin 2010.

Pastusiak L., Polacy u narodzin Stanów Zjednoczonych, Warszawa 2016.

Pastusiak L., Polacy w wojnie o niepodlegtość Stanów Zjednoczonych. Kościuszko, Putaski i inni, Warszawa 2015.

Rostworowski E., Historia Powszechna. Wiek XVIII, Warszawa 1994.

Rozbicki M.J., Wirginia, Maryland i Karolina, [w:] Historia Stanów Zjednoczonych, red. M.J. Rozbicki, I. Wawrzyczek, Warszawa 1995, t. 1, s. 53-77.

${ }^{23}$ Vide: Thomas Jefferson do Jamesa Monroe, 20 maja 1782, The Papers of Thomas Jefferson, t. 6, s. 185; Z. Libiszowska, op. cit., s. 89-90; W. Szyszkowski, Twórcy Stanów Zjednoczonych. Waszyngton, Jefferson, Hamilton, Warszawa 1980, s. 193-194. 
Rusinowa I., Geneza Stanów Zjednoczonych Ameryki Pótnocnej. Unia z lat 1774-1783, Warszawa 1974.

Rusinowa I., Saratoga-Yorktown 1777-1781. Z dziejów wojny amerykańsko-angielskiej, Warszawa 1984.

Szyszkowski W., Twórcy Stanów Zjednoczonych. Waszyngton, Jefferson, Hamilton, Warszawa 1980.

Tindall G.B., Shi D.E., Historia Stanów Zjednoczonych, tłum. A. Bartkiewicz, H. Jankowska, J. Ruszkowski, Poznań 2002

Wawrzyczek I., Planting and Loving. Popular Sexual Mores in the Seventeenth - Century Chesapeake, Lublin 1998.

Katarzyna Stelmasiak

\section{VIRGINIA'S NATURAL CONDITIONS AS A WAR SITE DURING THE US INDEPENDENCE STRUGGLE IN 1780-1781}

Summary. This article presents the natural environment of Virginia and shows how it affected the military operations during the American revolution. Notes on the state of Virginia by Thomas Jefferson served as the source for describing the natural conditions of the state. Geographically, Virginia is an extremely privileged land. Beautifully situated on the Chesapeake Bay has a varied landscape. There are plains along the coast, and inland the surface is highland - mountainous. There are numerous rivers, and the largest of them - James and Potomac are considered deep estuaries to the Chesapeake Bay.

Because of the terrain and a small settlement, the war in Virginia took on a different character than in New England. Compact and maneuverable army of Lord Charles Cornwallis applied fast maneuvers. At the head of their way to attack, the English set gunners, and the artillery assigned an independent function. The strength of the cavalry was also appreciated, both in attack and in retreat. In turn, on the American side, the main burden of defense rested on militia troops.

The first war operations took place in Virginia in the autumn of 1780, but the actual offensive began in the spring of 1781 . The British occupied the state capital of Richmond, and Lord Cornwallis made a bold attempt to capture Governor Thomas Jefferson and some more important members of the state assembly. By a lucky coincidence, the Virginia government and legislature were warned of imminent danger, and Jefferson was escaping from his Monticello estate near Charlottesville, Central Virginia, 5 minutes before the English arrived.

The decisive battle took place at Yorktown. The French and American armies reached Virginia by land and sea in early September 1781, and faced Lord Cornwallis at twice his strength. The cornered and attacked Lord Cornwallis capitulated on October $19^{\text {th }}$. After the surrender, the hostilities ceased and the English declared themselves defeated in the US Revolutionary War.

Keywords: war, American revolution, Virginia, natural conditions, XVIII century 